\title{
ADMINISTRACYJNOPRAWNE FORMY INGERENCJI EUROPEJSKICH ORGANÓW NADZORU NA RYNKU FINANSOWYM UNII EUROPEJSKIEJ
}

\begin{abstract}
WSTĘP
Podstawowym celem nadzoru nad rynkami finansowymi w gospodarkach rynkowych niezmiennie pozostaje zapewnienie stabilności rynków ${ }^{1}$, bezpieczeństwa obrotu i zaufania uczestników. Nie sposób jednak nie zauważyć faktu, że zmieniają się sfery ingerencji prawodawcy wspólnotowego, co związane jest immanentnie $\mathrm{z}$ postępującą integracją. $\mathrm{O}$ ile zatem w początkowej fazie funkcjonowania jednolitego rynku podstawowe znaczenie miało wprowadzenie wspólnych standardów dla podejmowania, prowadzenia i zakończenia działalności instytucji finansowych i ujednolicenia norm dotyczących nadzoru w tym zakresie, to obecnie owa zbieżność standardów wymusza coraz większą zbieżność również w procesie stosowania prawa. Niezależnie od powyższego nie sposób nie wspomnieć o tym, że zmiany prawa w coraz większym stopniu uwzględniają wpływ na stabilność nie tyle poszczególnych państw, co całej Wspólnoty².

Z uwagi na powyższe coraz większego znaczenia nabierają mechanizmy dyscyplinujące działania uczestników rynku. Mogą one mieć dwojaką naturę: regulacyjną bądź rynkową. Na dyscyplinę rynkową i regulacyjną składają się natomiast

1 Jak wskazano w punkcie 1 preambuły do rozporządzenia Parlamentu Europejskiego i Rady (UE) nr 1092/2010 z dnia 24 listopada 2010 r. w sprawie unijnego nadzoru makroostrożnościowego nad systemem finansowym i ustanowienia Europejskiej Rady ds. Ryzyka Systemowego (Dz. Urz. UE Nr L 331, s. 1 i n.), „stabilność finansowa jest podstawowym warunkiem, który musi zostać spełniony, aby realna gospodarka mogła zapewnić miejsca pracy, kredyty i wzrost gospodarczy".

2 A. Zalcewicz, Zmiana struktury instytucjonalnej $i$ koncepcji nadzoru nad jednolitym rynkiem finansowym UE, [w:] System finansów publicznych. Prawo finansowe wobec wyzwań XXI wie$k u$, red. A. Dobaczewska, E. Juchniewicz, T. Sowiński, Wydawnictwo CeDeWu, Warszawa 2010, s. 236-237.
\end{abstract}


dwa procesy: monitorowanie ryzyka działalności pośredników finansowych oraz oddziaływanie na decyzje ich kierownictw. Dyscyplinę rynkową sprawują głównie kapitałodawcy, regulacyjną zaś specjalne organy nadzoru finansowego, a także banki centralne i instytucje gwarantujące depozyty lub wypłacające inwestorom rekompensaty ${ }^{3}$.

Konsekwencją powyższych procesów jest zmiana optyki oraz - co wymaga podkreślenia - również mechanizmów działania organów nadzoru 4 .

\section{ZMIANY ARCHITEKTURY NADZORU NAD RYNKIEM FINANSOWYM UE}

Wskazuje się, że kryzys finansowy ujawnił istotne braki w nadzorze finansowym, który nie był w stanie przewidzieć negatywnych zmian o charakterze makroostrożnościowym i zapobiec nagromadzeniu się nadmiernych ryzyk w obrębie systemu finansowego ${ }^{5}$. Problemy te stały się przedmiotem prac organów wspólnotowych, mających na celu wypracowanie nowej, efektywnej architektury nadzoru nad rynkiem finansowym $\mathrm{UE}^{6}$. W listopadzie 2008 r. Komisja zleciła grupie wysokiego szczebla pod przewodnictwem Jacques'a de Larosière'a, byłego dyrektora generalnego Międzynarodowego Funduszu Walutowego, opracowanie zaleceń dla Komisji w sprawie wzmocnienia europejskich rozwiązań w zakresie nadzoru, aby lepiej chronić obywateli i odbudować zaufanie do systemu finansowego. Efektem

3 K. Jackowicz, Dyscyplina rynkowa na integrujacych sie rynkach finansowych Unii Europejskiej, [w:] Integracja rynków finansowych w Unii Europejskiej od $A$ do Z, red. M. Iwanicz-Drozdowska, Narodowy Bank Polski, Warszawa 2009, s. 258-261.

4 Szerzej zob. A. Michór, Administracyjnoprawna ingerencja na rynku finansowym, [w:] Przeglad dyscyplin badawczych pokrewnych nauce prawa i postępowania administracyjnego, red. S. Wrzosek, M. Domagała, J. Izdebski, T. Stanisławski, Wydawnictwo KUL, Lublin 2010, s. 425 i n. W sprawie modeli nadzoru nad rynkami finansowymi por. również uwagi T. Nieborak, Nowe podejście do kwestii nadzoru finansowego, „Prawo Bankowe” 2006, nr 5, s. 21-36.

5 Zob. pkt 1 preambuły do rozporządzenia nr 1092/2010.

6 Szerzej o przebiegu procesu legislacyjnego oraz dotychczasowych unormowaniach zob. A. Jurkowska-Zeidler, Nowe europejskie ramy ochrony stabilności wewnętrznego rynku finansowego, [w:] System finansów, s. 195 i n.; eadem, Bezpieczeństwo rynku finansowego w świetle prawa Unii Europejskiej, Wolters Kluwer, Warszawa 2008; M. Fedorowicz, Normatywne aspekty regulacji europejskiego nadzoru finansowego ze szczególnym uwzględnieniem europejskiego nadzoru w prawie bankowym, [w:] System finansów, s. 300 i n.; T. Nieborak, Europejski zintegrowany nadzór finansowy - aspekty instytucjonalno-prawne, [w:] Bezpieczeństwo rynku finansowego, red. E. Fojcik-Mastalska, E. Rutkowska-Tomaszewska, Prawnicza i Ekonomiczna Biblioteka Cyfrowa, Wrocław 2010, s. 51 i n.; A. Zalcewicz, op. cit., s. 231 i n.; A. Pilecka, Plan dziatań w zakresie ustug finansowych (FSAP) -zatożenia, realizacja i wptyw na rynki finansowe w Unii Europejskiej, [w:] Integracja rynkórw, s. 25 i n.; A. Michór, op. cit., s. 430 i n. 
prac grupy był raport końcowy przedstawiony w dniu 25 lutego 2009 r. $^{7}$ Zawierał on zrównoważoną i pragmatyczną wizję nowego systemu europejskiego nadzoru finansowego, w której centrum znalazły się propozycje wzmocnienia współpracy i koordynacji pomiędzy krajowymi organami nadzoru, w tym przez stworzenie nowych europejskich organów nadzoru i po raz pierwszy podmiotu na szczeblu europejskim obarczonego zadaniem nadzorowania zagrożeń, na które narażony jest system finansowy jako całość.

Owocem prac grupy stało się przyjęcie dnia 24 listopada 2010 r. rozporządzeń Parlamentu Europejskiego i Rady ustanawiających Europejski Urząd Nadzoru Bankowego (European Banking Authority - EBA), Europejski Urząd Nadzoru Giełd i Papierów Wartościowych (European Securities and Markets Authority - ESMA) ${ }^{8}$, ustanawiającego Europejski Urząd Nadzoru Ubezpieczeń i Pracowniczych Programów Emerytalnych (European Insurance and Occupational Pensions Authority - EIOPA $)^{9}$, dyrektywy „Omnibus” ${ }^{10}$, rozporządzenia Parlamentu Europejskiego i Rady (UE) nr 1092/2010 z dnia 24 listopada 2010 r. w sprawie unijnego nadzoru makroostrożnościowego nad systemem finansowym i ustanowienia Europejskiej Rady ds. Ryzyka Systemowego. Nadto 17 listopada 2010 r. przyjęto rozporządzenie Rady (UE) nr 1096/2010 w sprawie powierzenia Europejskiemu Bankowi Centralnemu szczególnych zadań w zakresie funkcjonowania Europejskiej Rady ds. Ryzyka Systemowego ${ }^{11}$.

Pierwsze trzy rozporządzenia weszły co do zasady w życie następnego dnia po ich opublikowaniu w Dzienniku Urzędowym Unii Europejskiej, to jest 16 grudnia 2010 r., stosuje się je od dnia 1 stycznia 2011 r., z wyjątkiem art. 76 i art. 77 ust. 1 i 2 rozporządzeń, które stosuje się od dnia wejścia w życie rozporządzeń. Urzędy ustanowiono z dniem 1 stycznia 2011 r. Natomiast rozporządzenie

7 Zob. Raport Grupy de Larosière'a z 25.02.2009 r., http://ec.europa.eu/internal_market/finances/docs/de_larosiere_report_pl.pdf

8 Rozporządzenie Parlamentu Europejskiego i Rady (UE) nr 1095/2010 z dnia 24 listopada 2010 r. w sprawie ustanowienia Europejskiego Urzędu Nadzoru (Europejskiego Urzędu Nadzoru Giełd i Papierów Wartościowych), zmiany decyzji nr 716/2009/WE i uchylenia decyzji Komisji 2009/77/WE, Dz. Urz. UE Nr L 331, s. 84 i n.

9 Rozporządzenie Parlamentu Europejskiego i Rady (UE) nr 1094/2010 z dnia 24 listopada 2010 r. w sprawie ustanowienia Europejskiego Urzędu Nadzoru (Europejskiego Urzędu Nadzoru Ubezpieczeń i Pracowniczych Programów Emerytalnych), zmiany decyzji nr 716/2009/WE i uchylenia decyzji Komisji 2009/79/WE, Dz. Urz. UE Nr L 331, s. 48 i n.

10 Dyrektywa Parlamentu Europejskiego i Rady 2010/78/UE z dnia 24 listopada 2010 r. w sprawie zmiany dyrektyw 98/26/WE, 2002/87/WE, 2003/6/WE, 2003/41/WE, 2003/71/WE, 2004/39/WE, 2004/109/WE, 2005/60/WE, 2006/48/WE, 2006/49/WE i 2009/65/WE w odniesieniu do uprawnień Europejskiego Urzędu Nadzoru (Europejskiego Urzędu Nadzoru Bankowego), Europejskiego Urzędu Nadzoru (Europejskiego Urzędu Nadzoru Ubezpieczeń i Pracowniczych Programów Emerytalnych) oraz Europejskiego Urzędu Nadzoru (Europejskiego Urzędu Nadzoru Giełd i Papierów Wartościowych), Dz. Urz. UE Nr L 331, s. 120 i n.

11 Dz. Urz. UE Nr L 331, s. 162 i n. 
w sprawie unijnego nadzoru makroostrożnościowego oraz rozporządzenie Rady (UE) nr 1096/2010 weszły w życie 16 grudnia 2010 r., dyrektywa „Omnibus” zaś 4 stycznia $2011 \mathrm{r}$.

Ramy prawne europejskiego nadzoru nad rynkami finansowymi składają się z filaru mikroostrożnościowego i makroostrożnościowego.

Filar mikroostrożnościowy tworzy Europejski System Nadzoru Finansowego - ESNF (European System of Financial Supervisors - ESFS) składający się z sieci krajowych organów nadzoru finansowego współpracujących z nowymi europejskimi organami nadzoru (EBA, ESMA oraz EIOPA ${ }^{12}$ ). Celem ESFN jest czuwanie nad stabilnością finansową na poziomie poszczególnych przedsiębiorstw finansowych oraz ochrona konsumentów usług finansowych Opiera się na podziale obowiązków oraz ich wzajemnym umacnianiu, łącząc nadzór krajowy nad przedsiębiorstwami z centralizacją konkretnych zadań na poziomie europejskim, w celu promowania harmonizacji przepisów, jak również spójnych praktyk nadzorczych oraz ich wdrażania. Jej celem ma być zwiększenie zaufania pomiędzy krajowymi organami nadzoru, m.in. przez dopilnowanie, aby organy nadzoru przyjmującego Państwa Członkowskiego miały odpowiedni udział w określaniu polityk dotyczących stabilności finansowej oraz ochrony konsumentów, umożliwiając tym samym bardziej skuteczne przeciwdziałanie zagrożeniom transgranicznym ${ }^{13}$.

W zakresie nadzoru makroostrożnościowego utworzona została nowa Europejska Rada ds. Ryzyka Systemowego - ERRS (European Systemic Risk Board - ESRB), która ma monitorować i oceniać zagrożenia dla stabilności systemu finansowego jako całości. Oparta jest na zasadzie podziału obowiązków oraz ich wzajemnego umacniania, łącząc nadzór krajowy nad przedsiębiorstwami z centralizacją konkretnych zadań na poziomie europejskim, w celu promowania harmonizacji przepisów, jak również spójnych praktyk nadzorczych oraz ich wdrażania. Do zasad działania sieci należą partnerstwo, elastyczność i pomocniczość ${ }^{4}$. Wskazuje się przy tym, że podstawowe znaczenie dla filaru makroostrożnościowe-

12 Zastąpiły one dotychczasowe komitety - Komitet Europejskich Organów Nadzoru Rynku Papierów Wartościowych (Committee of European Securities Regulators - CESR), Komitet Europejskich Organów Nadzoru Bankowego (Committee of European Banking Supervision - CEBS) oraz Komitet Europejskich Organów Nadzoru Ubezpieczeń i Emerytur Pracowniczych (Committee of European Insurance and Occupational Pension Supervision - CEIOPS).

13 Zob. Komunikat Komisji z dnia 27 maja 2009 r. - Europejski nadzór finansowy, KOM(2009) 252 wersja ostateczna, http://eur-lex.europa.eu/LexUriServ/LexUriServ.do?uri=COM:2009:0252:FIN: PL:PDF. Zob. również A. Zalcewicz, op. cit., s. 231 i n. oraz P. Stanisławiszyn, Perspektywy zmian europejskich regulacji w zakresie nadzoru finansowego w 2011 r., [w:] Wyzwania regulacyjne wobec doświadczeń globalnego kryzysu finansowego, red. J. Szambelańczyk, Oficyna Wydawnicza SGH w Warszawie, Warszawa 2011, s. 136 i n.

14 Zob. Komunikat Komisji z dnia 27 maja 2009 r.- Europejski nadzór finansowy, KOM(2009) 252 wersja ostateczna. Por. także A. Jurkowska-Zeidler, Nowe europejskie, s. 195 i n. 
go będzie miała działalność EBC oraz banków centralnych, ponieważ dysponują one wiedzą ekspercką i spoczywają już na nich obowiązki w dziedzinie stabilności finansowej $j^{15}$.

Jednocześnie należy podkreślić, że nadzór makroostrożnościowy stanowi integralny element nowych rozwiązań nadzorczych, będąc ściśle związanym z zadaniami w zakresie nadzoru mikroostrożnościowego, powierzonego ESFS, wyposażonemu w nowe instrumenty prawnego oddziaływania na uczestników rynku finansowego. Wskazuje się, że wdrożenie owych rozwiązań uwzględniających współzależność między zagrożeniami mikro- i makroostrożnościowymi pomaga w budowie efektywnej struktury nadzorczej w UE, zdolnej do przeciwdziałania zagrożeniom globalnego rynku finansowego, w szczególności monitorowania transgranicznej działalności finansowej ${ }^{16}$.

\section{FORMY INGERENCJINA WSPÓLNOTOWYM RYNKU FINANSOWYM}

\section{UWAGI OGÓLNE}

Dotychczas większość unormowań wspólnotowych regulujących obrót instrumentami finansowymi miała charakter dyrektyw (m.in. zob. dyrektywy MiFID I ${ }^{17}, 2003 / 71^{18}, \mathrm{MAD}^{19} \mathrm{i} \mathrm{CRD}^{20}$ ). Wynikało to z czterostopniowego podejścia do tworzenia prawa ${ }^{21}$ oraz zasady subsydiarności prawa wspólnotowego. Rozpo-

\footnotetext{
15 Zob. pkt 24 preambuły do rozporządzenia nr 1092/2010; M. Fedorowicz, op. cit., s. 302

16 M. Fedorowicz, Kompetencje regulacyjne Europejskiego Urzędu Nadzoru Bankowego w zakresie przeciwdziatania kryzysowi finansowemu, [w:] Wyzwania regulacyjne, s. 116.

17 Dyrektywa nr 2004/39/WE Parlamentu Europejskiego i Rady z dnia 21 kwietnia 2004 r. w sprawie rynków instrumentów finansowych zmieniająca dyrektywę Rady 85/611/EWG i 93/6/ /EWG i dyrektywę 2000/12/WE Parlamentu Europejskiego i Rady oraz uchylająca dyrektywę Rady 93/22/EWG, Dz. Urz. UE L z 2004 r., Nr 145, s. 1 i n. z późn. zm.

18 Dyrektywa nr 2003/71/WE Parlamentu Europejskiego i Rady z dnia 4 listopada 2003 r. $\mathrm{w}$ sprawie prospektu emisyjnego publikowanego w związku z publiczną ofertą lub dopuszczeniem do obrotu papierów wartościowych i zmieniająca dyrektywę 2001/34/WE, Dz. Urz. UE L z 2003 r., Nr 345, s. 64 i n. z późn. zm.

19 Dyrektywa nr 2003/6/WE Parlamentu Europejskiego i Rady z dnia 28 stycznia 2003 r. w sprawie wykorzystania poufnych informacji i manipulacji na rynku (nadużyć na rynku; dyrektywa MAD), Dz. Urz. UE L z 2003 r., Nr 96, s. 16 i n. z późn. zm.

20 Dyrektywa nr 2006/49/WE Parlamentu Europejskiego i Rady z dnia 14 czerwca 2006 r. w sprawie adekwatności kapitałowej firm inwestycyjnych i instytucji kredytowych (wersja przeredagowana), Dz. Urz. WE z 2006 r., Nr 177, s. 201 i n. z późn. zm. Zob. A. Pilecka, op. cit., s. 26 i n. Zob. także T. Kowalak, Integracja transgraniczna rynku kapitatowego w Unii Europejskiej, [w:] Integracja rynków, s. 97 i n.

21 Szerzej w sprawie czterostopniowego podejścia do tworzenia prawa zob. A. Jurkowska-Zeidler, Bezpieczeñstwo rynku, s. 430-432.
} 
rządzenia na rynkach finansowych regulowały natomiast - co do zasady - jedynie kwestie techniczne, związane $\mathrm{z}$ obrotem instrumentami finansowymi ${ }^{22}$.

Tymczasem nowe rozwiązania w zakresie kompetencji wspólnotowych organów nadzoru opierają się na rozporządzeniach, który przydają tym organom wiele nowych kompetencji i zadań. Szczególnego podkreślenia wymaga fakt wprowadzenia możliwości wydawania $\mathrm{w}$ sytuacjach określonych $\mathrm{w}$ rozporządzeniach przez nowe organy mikroostrożnościowe w stosunku do instytucji finansowych wiążących decyzji administracyjnych ${ }^{23}$. $Z$ jednej strony umożliwia to wykonywanie efektywnego nadzoru nad instytucjami finansowymi, z drugiej jednak rodzi poważne wątpliwości związane ze skutkami takich decyzji ${ }^{24}$. Konieczne jest zatem zasygnalizowanie kluczowych problemów związanych z nowymi ramami nadzoru.

\section{NADZÓR MIKROOSTROŻNOŚCIOWY}

EBA, ESMA oraz EIOPA przydano analogiczne uprawnienia, z pewnymi odrębnościami wynikającymi z cech segmentów rynku, na których organy te działają ${ }^{25}$. Zadania urzędów zostały określone w artykułach 8 ust. 1 oraz 9 rozporządzeń - odpowiednio - 1093/2010, 1094/2010 i 1095/201026. Natomiast uprawnienia mające na celu realizację powyższych zadań zostały przykładowo wymienione w artykułach 8 ust. 2 wskazanych wyżej rozporządzeń. Doprecyzowanie tych form ingerencji znajduje się natomiast $\mathrm{w}$ dalszych częściach rozporządzeń. W opracowaniu chciałbym przy tym skupić się na problematyce regulacyjnych i wykonawczych standardów technicznych, wytycznych i zaleceń oraz decyzji administracyjnych.

22 A. Michór, Odpowiedzialność administracyjna w obrocie instrumentami finansowymi, Wolters Kluwer, Warszawa 2009, s. 60 i n. Por. rozporządzenie Komisji nr 2273/2003 z dnia 22 grudnia 2003 r. wykonujące dyrektywę 2003/6/WE Parlamentu Europejskiego i Rady w odniesieniu do zwolnień dla programów odkupu i stabilizacji instrumentów finansowych, Dz. Urz. UE L z 2003 r., Nr 336, s. 33 i n.

23 M. Fedorowicz, Kompetencje regulacyjne, s. 112-113.

24 Por. uwagi P. Stanisławiszyna, op. cit., s. 137.

25 Por. art. 8 ust. 1 lit. f in fine oraz lit. h rozp. 1093/2010.

26 Należą do nich m.in. przyczynianie się do ustanowienia wspólnych standardów i praktyk regulacyjnych i nadzorczych o wysokiej jakości, w szczególności przez przedstawianie opinii instytucjom Unii oraz przez opracowywanie wytycznych, zaleceń i projektów regulacyjnych i wykonawczych standardów technicznych; ścisła współpraca z ERRS, w szczególności przez dostarczanie jej wszelkich informacji koniecznych do realizacji jej zadań oraz przez zapewnianie podejmowania odpowiednich działań następczych w związku z jej ostrzeżeniami i zaleceniami; przeprowadzanie analizy ekonomicznej rynków w celu informowania o wykonywaniu zadań przez Urzędy; wzmacnianie ochrony inwestorów; Urzędy podejmują przewodnią rolę w propagowaniu przejrzystości, prostoty i uczciwości na rynku konsumenckich produktów i usług finansowych całego rynku wewnętrznego. 
W pierwszym rzędzie należy zwrócić uwagę na uprawnienia EBA, ESMA oraz EIOPA do opracowywania projektów regulacyjnych (artykuły 10 rozporządzeń) i wykonawczych standardów technicznych (artykuły 15 rozporządzeń).

W preambułach do rozporządzeń 1093/2010, 1094/2010 i 1095/2010 wskazano, że istnieje potrzeba wprowadzenia skutecznego instrumentu ustanawiającego zharmonizowane regulacyjne standardy techniczne w zakresie usług finansowych, tak by zapewnić, również przez jednolity zbiór przepisów, równe warunki i odpowiednią ochronę deponentów, inwestorów i konsumentów w całej Uniii ${ }^{27}$.

Zgodnie z artykułami 10 ust. 1 rozporządzeń 1093/2010, 1094/2010 i 1095/2010 w przypadku przekazania Komisji przez Parlament Europejski i Radę uprawnień do przyjmowania regulacyjnych standardów technicznych w drodze aktów delegowanych zgodnie z art. $290 \mathrm{TFUE}^{28} \mathrm{w}$ celu zapewnienia spójnej harmonizacji w dziedzinach szczegółowo określonych w aktach ustawodawczych, o których mowa w art. 1 ust. 2 ww. rozporządzeń, Urząd może opracować projekty regulacyjnych standardów technicznych. Urząd przedstawia Komisji swoje projekty standardów do zatwierdzenia. Co prawda regulacyjne standardy techniczne mają charakter wyłącznie techniczny, nie mogą rozstrzygać kwestii strategicznych ani kwestii dotyczących polityki, a zakres ich treści wyznaczają akty ustawodawcze, które stanowią ich podstawę, jednak z uwagi na specjalistyczną wiedzę techniczną w dziedzinie usług finansowych, wymaganą dla przygotowania projektów standardów ${ }^{29}, \mathrm{w}$ istocie to na Urzędach spoczywać będzie główny ciężar uporządkowania rynku we wskazanym wyżej zakresie ${ }^{30}$.

Analogiczna sytuacja występuje w odniesieniu do wykonawczych standardów technicznych. Zgodnie z artykułami 15 ww. rozporządzeń Urzędy mogą opracować wykonawcze standardy techniczne - w drodze aktów wykonawczych zgodnie z art. 291 TFUE - w dziedzinach szczegółowo określonych w aktach ustawodawczych, o których mowa w art. 1 ust. 2 rozporządzeń. Wykonawcze standardy techniczne mają charakter wyłącznie techniczny, nie mogą rozstrzygać kwestii strategicznych ani wyborów w zakresie polityki, a ich treść ma na celu określenie warunków zastosowania tych aktów. Urząd przedstawia Komisji projekty wykonawczych standardów technicznych do zatwierdzenia.

27 Zob. punkt 22 preambuły do rozporządzenia 1093/2010, punkt 21 preambuły do rozporządzenia 1094/2010, punkt 22 preambuły do rozporządzenia 1095/2010.

28 Traktat o funkcjonowaniu Unii Europejskiej, wersja skonsolidowana z 2008 r. - Dz. Urz. UE C, Nr 115, s. 47 i n.

${ }_{29}$ Por. punkty 21 i n. preambuł do rozporządzeń 1093/2010, 1094/2010 i 1095/2010.

30 Por. uwagi M. Fedorowicz, Kompetencje regulacyjne, s. 118-119. W tym miejscu należy przy tym zwrócić uwagę na określenie procedury przyjęcia regulacyjnego standardu technicznego w przypadku nieprzedłożenia projektu przez Urzędy - zob. art. 10 ust. 3 rozporządzeń 1093/2010, 1094/2010 i 1095/2010. 
Kolejnym instrumentem ingerencji EBA, ESMA oraz EIOPA na rynkach finansowych jest wydawanie wytycznych i zaleceń skierowanych do właściwych organów lub instytucji finansowych (artykuły 16 rozporządzeń). Ich celem jest ustanowienie spójnych, wydajnych i skutecznych praktyk nadzorczych w ramach ESNF oraz zapewnienie wspólnego, jednolitego i spójnego stosowania prawa Unii. Jednocześnie na właściwe organy i instytucje finansowe nałożono obowiązek dołożenia wszelkich starań, aby zastosować się do tych wytycznych i zaleceń. W piśmiennictwie wskazuje się, że $z$ uwagi na sformułowanie, że adresaci „dokładają wszelkich starań, można by wywodzić wniosek, że wytyczne i zalecenia nie mają wiążącego charakteru. Jednocześnie jednak prawodawca europejski w istocie „wymusza” na adresatach ich przestrzeganie ${ }^{31}$. W rozporządzeniach ustanowiono przy tym procedurę kontrolną - w ciągu dwóch miesięcy od wydania wytycznej lub zalecenia każdy właściwy organ potwierdza, czy stosuje się lub czy zamierza zastosować się do danej wytycznej lub danego zalecenia. Jeżeli właściwy organ nie stosuje się do nich, ani nie zamierza się do nich zastosować, powiadamia o tym Urząd, podając uzasadnienie. Środkiem dyscyplinującym jest opublikowanie informacji o tym, że dany właściwy organ nie stosuje się lub nie zamierza zastosować się do danej wytycznej lub danego zalecenia. Nadto Urząd może, w odniesieniu do indywidualnych przypadków, podjąć decyzję o opublikowaniu przedstawionego przez właściwy organ uzasadnienia niezastosowania się do danej wytycznej lub danego zalecenia. Właściwy organ jest $\mathrm{z}$ wyprzedzeniem powiadamiany o takiej publikacji. Publikacja taka zwraca uwage uczestnikom obrotu na wadliwe działanie krajowego organu nadzoru, pełniąc w tym zakresie funkcję sygnalizacyjną. Środek taki nie jest pozbawiony znaczenia $\mathrm{z}$ uwagi na dużą wrażliwość rynków finansowych na wszelkie negatywne informacje. Niezależnie od powyższego, jeżeli jest to wymagane w wytycznej lub zaleceniu, instytucje finansowe jasno i szczególowo informują, czy stosują się do tej wytycznej lub zalecenia.

Nowym instrumentem przydanym wspólnotowym organom nadzoru jest umocowanie do wydawania decyzji administracyjnych, które mogą być kie-

31 Podnosi się, że w sytuacjach, gdy wytyczne adresowane będą do krajowych organów nadzoru, pośrednio dotyczyć będą również instytucji finansowych, ponieważ treść normatywna zawarta w tych aktach uwzględniona będzie również w prawotwórczej działalności krajowych organów nadzoru. W konsekwencji w przypadku sporu instytucji finansowych z krajowymi organami nadzoru instytucje finansowe będą mogły korzystać z ochrony prawnej. M. Lehman, C. Manger-Nestler, Die Vorschläge zur neuen Architektur der europäischen Finanzaufsicht, „Europäische Zeitschrift für Wirtschaftsrecht” 2010, Nr. 3, s. 91; M. Fedorowicz, Kompetencje regulacyjne, s. 121. Natomiast w przypadku powstania sytuacji, w której z punktu widzenia prawa materialnego wytyczne okazałyby się instrumentem wkraczającym w sferę prawnej samodzielności instytucji finansowych, mogłoby dojść do kwestionowania możliwości posługiwania się tym instrumentem przez Urzędy. M. Fedorowicz, Kompetencje regulacyjne, s. 121. 
rowane tak do krajowych organów nadzoru, jak i do podmiotów indywidualnych. Decyzje te można przy tym podzielić na trzy grupy: decyzje wydawane w przypadku, gdy właściwy organ nie zastosował aktów unijnych (artykuły 17 rozporządzeń ${ }^{32}$ ), decyzje podejmowane w sytuacjach nadzwyczajnych (artykuły 18 rozporządzeń) oraz przy rozstrzyganiu sporów między właściwymi organami w sytuacjach transgranicznych (artykuły 19 rozporządzeń) ${ }^{33}$. Nie wnikając szerzej $\mathrm{w}$ kwestie związane $\mathrm{z}$ procedurą przyjęcia decyzji oraz ich przesłanka$\mathrm{mi}^{34}$, chciałbym skupić się na problemie skutków decyzji wydanych przez Urzędy oraz ich charakterze prawnym w kontekście krajowego porządku prawnego. Zgodnie bowiem $\mathrm{z}$ art. 17 ust. 7 , art. 18 ust. 5 i art. 19 ust. 5 decyzje skierowane do podmiotów indywidualnych mają pierwszeństwo wobec wszelkich decyzji przyjętych wcześniej przez właściwe organy w tej samej sprawie. Należy zatem rozważyć skutki wydania decyzji przez Urzędy, która - w istocie - zastąpi decyzje krajowych organów nadzoru. Konsekwencją powyższego będą problemy związane choćby z kwestią wzruszalności decyzji administracyjnej, skutkami decyzji ostatecznych i prawomocnych. Nowa regulacja w żaden sposób do tych zagadnień się nie odnosi. Konsekwencją powyższego może być zatem konieczność zmiany krajowych regulacji prawnych, w tym kodeksu postępowania administracyjnego. Wątpliwości budzi również przedmiotowe określenie zakresu, w jakim dochodzi do zastąpienia decyzji krajowych organów nadzoru przez decyzje Urzędów. Urzędy te umocowano bowiem do wydania decyzji indywidualnej zobowiązującej instytucję finansową „do podjęcia działań niezbędnych do wypełnienia jej obowiązków wynikających z tego prawodawstwa, w tym do zaprzestania określonych praktyk". Czy owo pierwszeństwo oznacza, że dochodzi do swego rodzaju wzruszenia wszystkich decyzji krajowych organów nadzoru podjętych w sprawie naruszenia przez instytucję finansową jej obowiązków? Wydaje się, że nie. W pierwszym rzędzie należy zwrócić uwagę na fakt, że decyzja EBA w istocie nie będzie tożsama pod względem przedmiotowym ze wszystkimi decyzjami krajowych organów nadzoru związanymi z naruszeniem prawa przez instytucję finansową ${ }^{35}$.

32 Chodzi tutaj o sytuacje, gdy właściwy organ nie zastosował aktów unijnych, o których mowa $\mathrm{w}$ art. 1 ust. 2, w tym regulacyjnych standardów technicznych i wykonawczych standardów technicznych ustanowionych zgodnie $\mathrm{z}$ art. 10-15, lub zastosował je w sposób, który wydaje się stanowić naruszenie prawa Unii, w szczególności nie zapewniając spełnienia przez instytucję finansową wymogów ustanowionych w tych aktach, Urząd podejmuje działania zgodnie z uprawnieniami określonymi w art. 17 ust. 2, 3 i 6 rozporządzeń.

33 Zob. M. Fedorowicz, Kompetencje regulacyjne, s. 123.

34 Szerzej zob. ibidem, s. 122-123.

35 A. Michór, Nowa europejska architektura nadzoru nad rynkiem bankowym, „Bezpieczny Bank” 2011, nr 1, s. 71 i n. 
Problemy może rodzić również wydanie przez Urzędy formalnej opinii nakładającej na właściwy organ krajowy obowiązku podjęcia działań niezbędnych do przestrzegania prawa Unii (art. 17 ust. 4 rozporządzeń) poprzedzającej wydanie decyzji skierowanej do instytucji finansowej (art. 17 ust. 6 rozporządzeń), decyzji skierowanych do krajowych organów nadzoru w sytuacjach nadzwyczajnych (art. 18 ust. 3 rozporządzeñ ${ }^{36}$ ) oraz decyzji skierowanych do krajowych organów nadzoru w przypadku sporów transgranicznych (art. 19 ust. 3 rozporządzenn ${ }^{37}$ ) poprzedzających wydawane $\mathrm{w}$ tych przypadkach decyzje indywidualne (art. 19 ust. 4 rozporządzeń ${ }^{38}$ ). Podkreślenia wymaga bowiem fakt, że unijny ustawodawca nie wskazał skutków wydania takich decyzji i opinii skierowanych do krajowych organów nadzoru w przypadku, gdy pośrednio takie decyzje bądź opinie wywierają skutki w stosunku do podmiotów indywidualnych. Pierwszym problemem będzie określenie stron postępowania administracyjnego, które rozporządzenia określają jako „adresatów decyzji” (zob. art. 39), natomiast w preambułach jako „zainteresowane strony" 39 . Jednocześnie w artykułach 39 nie ograniczono pojęcia adresata jedynie do decyzji skierowanych do indywidualnych administrowanych. Kolejnym problemem jest wskazanie w krajowym porządku prawnym podstawy prawnej wzruszenia ostatecznych czy nawet prawomocnych decyzji administracyjnych przez krajowe organy nadzoru na podstawie opinii bądź decyzji jednego z Urzędów. Zagadnienia te wymagają zatem doprecyzowania oraz interwencji ustawodawczej.

W piśmiennictwie wskazuje się również na fakt, że normodawca unijny nie wskazał zakresu ewentualnej odpowiedzialności związanej z uchyleniem decyzji krajowego organu nadzoru i zastąpieniu jej decyzją Urzędów ${ }^{40}$, związanej choćby z ochroną praw nabytych.

\footnotetext{
36 Zgodnie z tymi przepisami Urząd może przyjąć indywidualne decyzje zobowiązujące właściwe organy do podjęcia niezbędnych działań zgodnie z przepisami.

37 W myśl tych unormowań Urząd może - zgodnie z procedurą określoną w art. 44 ust. 1 akapit trzeci i czwarty rozporządzeń - w celu rozstrzygnięcia sporu wydać decyzję zobowiązującą te organy do podjęcia określonych działań lub do powstrzymania się od działań, ze skutkami wiążącymi dla zainteresowanych właściwych organów, aby zapewnić zgodność z prawem Unii.

38 Wedle tych regulacji bez uszczerbku dla uprawnień Komisji na mocy art. 258 TFUE, w przypadku gdy właściwy organ nie stosuje się do decyzji Urzędu, a w ten sposób nie zapewnia spełniania przez instytucję finansową wymogów, które stosowane są wobec niej bezpośrednio na mocy aktów, o których mowa w art. 1 ust. 2 rozporządzeń, Urząd może wydać skierowaną do instytucji finansowej decyzję indywidualną, zobowiązującą tę instytucję do podjęcia działań niezbędnych do wypełnienia jej obowiązków wynikających z prawa Unii, w tym do zaprzestania określonych praktyk.

Zob. pkt 58 preambuly do rozporządzenia 1093/2010, pkt 59 preambuły do rozporządzenia 1094/2010, pkt 58 preambuły do rozporządzenia 1095/2010.

$40 \quad$ P. Stanisławiszyn, op. cit., s. 137.
} 
W końcu wątpliwości budzi samo przydanie Urzędom kompetencji do wydawania decyzji administracyjnych w kontekście regulacji traktatowych, które takiej możliwości nie przewidują ${ }^{41}$.

Resumując - o ile samo przydanie unijnym Urzędom kompetencji do wydawania decyzji administracyjnych należy ocenić pozytywnie $z$ uwagi na umożliwienie przeprowadzenia efektywnej ingerencji na rynku, to sposób owego umocowania budzi wiele wątpliwości.

\section{FILAR MAKROOSTROŻNOŚCIOWY}

Ingerencja makroostrożnościowa opiera się na działaniach Europejskiej Rady ds. Ryzyka Systemowego. Ma ona monitorować i oceniać zagrożenia dla stabilności systemu finansowego jako całości. Jednocześnie nadzór ten powiązany jest z nadzorem mikroostrożnościowym z uwagi na fakt, że w skład Rady wchodzą Urzędy Nadzoru oraz właściwe organy lub organy nadzorcze państw członkowskich (art. 1 ust. 3 lit. B-d i f rozporządzenia nr 1092/2010). Zgodnie $\mathrm{z}$ art. 3 ust. 1 rozporządzenia 1092/2010 ERRS jest odpowiedzialna za sprawowanie nadzoru makroostrożnościowego nad systemem finansowym w Unii w celu przyczyniania się do przeciwdziałania ryzykom systemowym dla stabilności finansowej w Unii, które pojawiają się w związku z wydarzeniami w obrębie systemu finansowego, lub ograniczania tych ryzyk, $z$ uwzględnieniem zmian natury makroekonomicznej, tak aby zapobiegać okresom rozpowszechnionego występowania trudności finansowych. ERRS przyczynia się do sprawnego funkcjonowania rynku wewnętrznego i tym samym zapewnia trwały wkład sektora finansowego we wzrost gospodarczy.

Dla realizacji powyższych zadań Rada m.in. wydaje ostrzeżenia w sytuacjach, gdy takie ryzyko systemowe jest uznawane za znaczące, i w stosownych przypadkach podaje te ostrzeżenia do wiadomości publicznej; wydaje zalecenia w sprawie działań zaradczych w odniesieniu do zidentyfikowanego ryzyka i, w stosownych przypadkach, podaje te zalecenia do wiadomości publicznej; wydaje poufne ostrzeżenia skierowane do Rady, w przypadku gdy ERRS uzna, że wkrótce może wystąpić sytuacja nadzwyczajna określona w art. 18 rozporządzenia (UE) nr 1093/2010, art. 18 rozporządzenia (UE) nr 1094/2010 i art. 18 rozporządzenia (UE) nr 1095/2010, i przedstawia ocenę sytuacji, aby Rada mogła określić, czy zachodzi potrzeba przyjęcia decyzji skierowanej do Europejskich Urzędów Nadzoru, w której stwierdza się wystąpienie sytuacji nadzwyczajnej; monitoruje

${ }^{41}$ Zob. M. Fedorowicz, Kompetencje regulacyjne, s. 124. 
działania następcze w związku $\mathrm{z}$ ostrzeżeniami i zaleceniami (art. 3 ust. 2 rozporządzenia 1092/2010) ${ }^{42}$.

Podkreślenia wymaga przy tym fakt, że ostrzeżenia i opinie Rady nie mają charakteru wiążącego, chociaż podmiotom, do których są skierowane, nie wolno pozostać względem nich bezczynnymi. Wskazuje się, że tak ostrzeżenia, jak i zalecenia powinny powodować podjęcie określonych działań przez ich adresatów, a nadto - w przypadku zaleceń - dodatkowo może zostać nałożony obowiązek przedstawienia informacji o wszystkich działaniach podjętych w odpowiedzi na zalecenia i przedstawienia odpowiedniego uzasadnienia w przypadku braku działania ${ }^{43}$. Nie można także nie zwrócić uwagi na możliwość podania do publicznej wiadomości faktu niewykonania zalecenia w trybie art. 17 ust. 3 i art. 18 rozporządzenia 1092/2010. W tym zakresie w pełni aktualne pozostaną uwagi dotyczące nadzoru mikroostrożnościowego.

\section{ZAKOŃCZENIE}

Nadzwyczajna sytuacja związana $z$ kryzysem na rynkach finansowych wymagała zmiany formuły nadzoru. Integracja rynków finansowych wiąże się z wieloma korzyściami, takimi jak wzrost gospodarczy bądź zmniejszenie kosztów transakcyjnych $^{44}$, może jednak powodować zagrożenia, które ujawniły się m.in. w związku

42 Zgodnie $\mathrm{z}$ art. 16 rozporządzenia 1092/2010 w przypadku zidentyfikowania znaczących ryzyk zagrażających osiągnięciu celu określonego w art. 3 ust. 1 ERRS wydaje ostrzeżenia oraz, w stosownych przypadkach, zalecenia w sprawie działań zaradczych, w tym, w stosownych wypadkach, w sprawie inicjatyw ustawodawczych. Ostrzeżenia lub zalecenia wydawane przez ERRS zgodnie z art. 3 ust. 2 lit. c) i d) rozporządzenia 1092/2010 mogą mieć charakter ogólny lub szczegółowy i są kierowane w szczególności do całej Unii lub do jednego państwa członkowskiego lub większej ich liczby lub do jednego Europejskiego Urzędu Nadzoru lub większej ich liczby lub do jednego krajowego organu nadzoru lub większej ich liczby. W przypadku gdy ostrzeżenie lub zalecenie jest kierowane do co najmniej jednego krajowego organu nadzoru, informuje się o tym również zainteresowane państwo członkowskie lub państwa członkowskie. Zalecenia zawierają konkretny termin na podjęcie właściwych działań. Zalecenia mogą być również kierowane do Komisji i dotyczyć stosownych przepisów unijnych. Ostrzeżenia lub zalecenia przekazywane adresatom są zgodnie z zasadami ścisłej poufności jednocześnie przekazywane również Radzie oraz Komisji, a jeżeli są skierowane do co najmniej jednego krajowego organu nadzoru, przekazuje się je również Europejskim Urzędom Nadzoru. W celu zwiększenia świadomości ryzyk zagrażających unijnej gospodarce i priorytetowego traktowania takich ryzyk ERRS, w ścisłej współpracy z innymi podmiotami wchodzącymi w skład ESNF, opracowuje system oznaczeń oparty na kolorach odpowiadających sytuacjom o różnych poziomach ryzyka. Po opracowaniu kryteriów takiej klasyfikacji ostrzeżenia i zalecenia ERRS wskazują, opierając się na indywidualnych sytuacjach i w stosownych przypadkach, do której kategorii należy dane zagrożenie.

43 A. Zalcewicz, op. cit., s. 232.

44 Por. K. Piech, Integracja rynków finansowych a gospodarka i jej wzrost, [w:] Integracja rynków, s. 58 i n. 
$\mathrm{z}$ kryzysem subprime, $\mathrm{w}$ tym wynikające $\mathrm{z}$ tzw. efektu zarażania (contagiom effect) ${ }^{45}$. Tradycyjne narzędzia stosowane przez organy administracji publicznej mogą być w takich przypadkach niewystarczające. Dotychczasowe rozwiązania nie zdały zatem egzaminu. W szczególności szwankowała wspólpraca transgraniczna między organami nadzoru, występowały nacjonalizmy polegające na chronieniu lokalnych podmiotów z pokrzywdzeniem podmiotów z innych państw. Jednocześnie wspólnotowe organy nadzoru nie posiadały efektywnych mechanizmów ingerencji na rynkach. Otwarta pozostaje natomiast kwestia, czy nowa architektura nadzoru spełni pokładane w niej nadziej i czy nie będzie konieczna zmiana przedmiotowych regulacji ${ }^{46}$. Na powyższe zagadnienia nakłada się problem nieprecyzyjności nowej regulacji w kontekście krajowych unormowań, co będzie skutkowało trudnościami w jej efektywnym stosowaniu.

\section{BIBLIOGRAFIA}

Fedorowicz M., Kompetencje regulacyjne Europejskiego Urzędu Nadzoru Bankowego w zakresie przeciwdziatania kryzysowi finansowemu, [w:] Wyzwania regulacyjne wobec doświadczeń globalnego kryzysu finansowego, red. J. Szambelańczyk, Oficyna Wydawnicza SGH w Warszawie, Warszawa 2011.

Fedorowicz M., Normatywne aspekty regulacji europejskiego nadzoru finansowego ze szczególnym uwzględnieniem europejskiego nadzoru w prawie bankowym, [w:] System finansów publicznych. Prawo finansowe wobec wyzwań XXI wieku, red. A. Dobaczewska, E. Juchniewicz, T. Sowiński, Wydawnictwo CeDeWu, Warszawa 2010.

Iwanicz-Drozdowska M., Integracja rynków finansowych-jej rodzaje i znaczenie, [w:] Integracja rynków finansowych w Unii Europejskiej od A do Z,red. M. Iwanicz-Drozdowska, Narodowy Bank Polski,Warszawa 2009.

Jackowicz K., Dyscyplina rynkowa na integrujacych się rynkach finansowych Unii Europejskiej, [w:] Integracja rynków finansowych w Unii Europejskiej od A do Z, red. M. Iwanicz-Drozdowska, Narodowy Bank Polski, Warszawa 2009.

Jurkowska-Zeidler A., Bezpieczeństwo rynku finansowego w świetle prawa Unii Europejskiej, Wolters Kluwer, Warszawa 2008.

Jurkowska-Zeidler A., Nowe europejskie ramy ochrony stabilności wewnętrznego rynku finansowego, [w:] System finansów publicznych. Prawo finansowe wobec wyzwañ XXI wieku, red. A. Dobaczewska, E. Juchniewicz, T. Sowiński, Warszawa 2010.

45 Por. M. Iwanicz-Drozdowska, Integracja rynków finansowych - jej rodzaje i znaczenie, [w:] Integracja rynków, s. 17, 20.

46 P. Stanisławiszyn zwraca uwagę na możliwość skorzystania w takim przypadku w zakresie nadzoru nad rynkiem bankowym $\mathrm{z}$ regulacji art. 127 ust. 6 TFUE i przejęcie inicjatywy na rynku bankowym przez Europejski Bank Centralny w zakresie polityki w dziedzinie nadzoru ostrożnościowego. P. Stanisławiszyn, op. cit., s. 137. 
Kowalak T., Integracja transgraniczna rynku kapitatowego w Unii Europejskiej, [w:] Integracja rynków finansowych w Unii Europejskiej od A do Z, red. M. Iwanicz-Drozdowska, Narodowy Bank Polski, Warszawa 2009.

Lehman M., Manger-Nestler C., Die Vorschläge zur neuen Architektur der europäischen Finanzaufsicht, „Europäische Zeitschrift für Wirtschaftsrecht” 2010, Nr. 3.

Michór A., Administracyjnoprawna ingerencja na rynku finansowym, [w:] Przeglad dyscyplin badawczych pokrewnych nauce prawa i postępowania administracyjnego, red. S. Wrzosek, M. Domagała, J. Izdebski, T. Stanisławski, Wydawnictwo KUL, Lublin 2010.

Michór A., Nowa europejska architektura nadzoru nad rynkiem bankowym, „Bezpieczny Bank” 2011, nr 1.

Michór A., Odpowiedzialnośc administracyjna w obrocie instrumentami finansowymi, Wolters Kluwer, Warszawa 2009.

Nieborak T., Europejski zintegrowany nadzór finansowy - aspekty instytucjonalno-prawne, [w:] Bezpieczeństwo rynku finansowego, red. E. Fojcik-Mastalska, E. Rutkowska-Tomaszewska, Prawnicza i Ekonomiczna Biblioteka Cyfrowa, Wrocław 2010.

Nieborak T., Nowe podejście do kwestii nadzoru finansowego, „Prawo Bankowe” 2006, nr 5.

Piech K., Integracja rynków finansowych a gospodarka i jej wzrost, [w:] Integracja rynków finansowych w Unii Europejskiej od A do Z, red. M. Iwanicz-Drozdowska, Narodowy Bank Polski, Warszawa 2009.

Stanisławiszyn P., Perspektywy zmian europejskich regulacji w zakresie nadzoru finansowego w 2011 r., [w:] Wyzwania regulacyjne wobec doświadczeń globalnego kryzysu finansowego, red. J. Szambelańczyk, Oficyna Wydawnicza SGH w Warszawie, Warszawa 2011.

Zalcewicz A., Zmiana struktury instytucjonalnej i koncepcji nadzoru nad jednolitym rynkiem finansowym UE, [w:] System finansów publicznych. Prawo finansowe wobec wyzwań XXI wieku, red. A. Dobaczewska, E. Juchniewicz, T. Sowiński, Wydawnictwo CeDeWu, Warszawa 2010.

\section{INNE ŹRÓDŁA}

Komunikat Komisji z dnia 27 maja 2009 r. - Europejski nadzór finansowy, KOM(2009) 252 wersja ostateczna, http://eur-lex.europa.eu/LexUriServ/LexUriServ.do?uri=COM:2009:0252:FIN:PL:PDF.

Raport Grupy de Larosière'a z 25.02.2009 r., http://ec.europa.eu/internal_market/finances/ docs/ de_larosiere_report_pl.pdf

\section{ADMINISTRATIVE AND LEGAL FORMS OF INTERFERENCE BY THE EUROPEAN REGULATORS IN THE FINANCIAL MARKET OF THE EUROPEAN UNION} SUMMARY

Financial stability is a precondition for the real economy to provide jobs, credit and growth. The financial crisis exposed important shortcomings in financial supervision, 
both in particular cases and in relation to the financial system as a whole. The problem is that nationally based supervisory models have lagged behind financial globalisation and the integrated and interconnected reality of European financial markets, in which many financial institutions operate across borders. The crisis exposed shortcomings in the areas of cooperation, coordination, consistent application of Union law and trust between national supervisors. The article deals with the issue of new regulations on supervision over financial markets of the EU as regards interference of administrative law into the financial market of the European Union. In particular the author considers the premises and nature of powers conferred on the new supervision authorities and draws attention to inconsistencies between the provisions of national law and the new UE regulations. 
